\title{
How Important are Insurers in Compensating Claims for Personal Injury in the U.K.?*
}

\author{
Richard Lewis \\ Professor of Law, Cardiff Law School, Cardiff University, Museum Avenue, Cardiff CF10 3XJ Wales, U.K. \\ E-mail: LewisRK@cf.ac.uk
}

To what extent does the institution of insurance influence a system of compensation for personal injury? On the one hand, some academics have suggested that insurance has been no more than a "makeweight" argument in the development of tort liability. On the other hand, others have claimed that insurance has had a substantial effect, even if this is often hidden or not discussed openly. This article lends support to one side of the debate by describing the enormous importance of insurers to personal injury litigation in the United Kingdom. It argues that all cases, in their wider context, have been affected by the practices of insurance companies. This is the case even though insurance is rarely mentioned by judges and largely ignored by textbooks on tort law. Insurers provide the lifeblood of the system.

The article examines statistics relating to the number of tort claims brought each year and it notes the extent of insurer involvement. As the paymasters of the system, insurers not only compensate claimants but also fund the cost of legal representation, often for both sides. Insurers have reduced their use of defence lawyers and the extent that they institute formal legal proceedings. However, it is their bureaucracy which determines whether, when and for how much claims are settled, and it is their offices, rather than courts of law, that are the key places for tort in practice. The scope for compensating those injured very much depends upon the incidence of insurance protection, and the amount of damages paid can only be understood against the insurance background. Finally, the article considers the influence of insurers upon potential changes in the law. The importance of insurers ought not to be underestimated; without insurance, the system of compensation for personal injury would have collapsed long ago.

The Geneva Papers (2006) 31, 323-339. doi:10.1057/palgrave.gpp.2510073

Keywords: personal injury; compensation; insurance; tort

\section{Introduction}

This article summarizes the structural importance of insurers to the system of compensation for personal injury in the U.K. It is part of a much wider study of the relationship between the rules of tort law, on the one hand, and the availability of insurance, on the other. ${ }^{1}$ It has been argued that judges appear more ready to impose

\footnotetext{
* This is a revised version of a paper delivered at the Third Annual Liability Regimes Conference held by Munich Re in Munich in October 2005. I am grateful to colleagues at Cardiff and delegates at the conference for their comments on the earlier paper.

${ }^{1}$ Lewis (2005b).
} 
liability when insurance enables the cost of compensation to be more widely distributed. ${ }^{2}$ Tort rules are said to have been developed in favour of claimants, at least in situations where they have been less able to protect themselves by taking out their own first party insurance. Others have denied that there is any consistent pattern in the law which reflects such a close relationship with insurance. ${ }^{3}$ However, here it is argued that the overall influence of insurers upon the system makes it difficult to view any tort case in isolation: each and every case is affected, no matter whether determined in court or out of it. The detailed rules of tort are not examined here. ${ }^{4}$ Instead we concentrate upon the institutional context within which tort law is practised and insurance functions in the U.K. How important are insurers to the litigation system and in what ways do they influence it?

The structure of this article falls into four broad and interrelated parts:

(1) The article first sets out the number of claims made each year for personal injury in the U.K. and argues that the real defendants in the great majority of these cases are not individuals but insurance companies. Insurers are the paymasters of the tort system, being responsible not only for the damages received by claimants but also the costs obtained by the lawyers on either side. Those who pay the piper also call the tune, and the influence insurers are able to bear as a result is considerable.

(2) The article next examines how the bureaucratic organization of insurance, rather than the payment of the parties, affects the course and the outcome of litigation. The structure of the insurance industry is such that the defence of claims is concentrated in the hands of only a few companies and law firms, and economic pressures mean that the vast majority of cases are settled out of court, many without the involvement of defence lawyers at all. Judges also have a very limited role to play, being involved in only one per cent of cases. The realities of the settlement system are such that, in practice, the strict rules of tort law are simplified and result in many more claimants obtaining compensation than the rules actually support. At the same time this liberal system can be seen as inequitable because success is dependent not upon theoretical liability rules but upon suffering the type of injury for which liability insurance has been made compulsory. Small claims are over-compensated, whereas victims of serious injury are under-compensated. This "lottery of litigation" is compounded by the pressures which the system places upon individual claimants with the result that those from a particular class or background will do better than others, but only rarely will they obtain the sums which would be awarded by a judge at trial.

(3) Consideration of the sums obtained by claimants leads us into the third part of the article which stresses the importance of insurers to the award of damages. Without a mechanism for distributing the resulting costs it would rarely be worth the time

\footnotetext{
${ }^{2}$ For example, Fleming (1948); Davies (1989); Morgan (2004).

${ }^{3}$ Stapleton (1995). Similarly, Prosser (1971, p. 547): "A dispassionate observer, if such a one is to be found in this area, might ... conclude that the 'impact' of insurance upon the law of torts has been amazingly slight ...."

${ }^{4}$ For extensive analysis of the case law see Lewis (2005a).
} 
and effort we presently expend to establish the liability to pay. Insurers provide the lifeblood of the system.

(4) The final section examines the influence of insurers upon government and the creation of legislation. The lobbying of insurers, especially in private, has been extremely effective in conserving the older and perhaps outdated values enshrined in the tort system. This leads to the final conclusion that without insurance the tort system could not have survived. It is beyond the scope of this article to consider what might have taken its place as a fairer and more efficient system of accident compensation. However, we are left with an appreciation of the importance of insurers to present tort law, and a denial of the claim that insurance has had only a limited effect upon the legal system.

\section{The number of claims}

Last year in the U.K. there were 755,000 claims brought for personal injury one for every 77 people. ${ }^{5}$ Although the previous year was responsible for a record number of claims, the overall trend shows that the underlying rate of claims has remained relatively constant since 1997 when new methods of recording claims were introduced. It is true that the overall number of claims had previously increased to reach a peak of 770,000 , but this increase was wholly attributable to the special circumstances which had caused an exceptional rise in disease claims as opposed to accidents.

What were these special circumstances? Disease claims rose almost threefold over the 2 years to 2004 , from 74,000 to 213,000 a year. This was the result of the impetus created by the imposition of a final date for bringing claims under the special compensation rules devised for particular diseases suffered by coalminers. Law firms intensively solicited these claims, and since 1999 they have registered over 740,000 of them. These coalmining claims supposedly constitute "the biggest personal injury

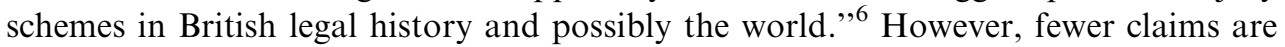
now being brought for other types of disease, and the extra difficulties of bringing such claims are well known. ${ }^{7}$

By contrast with the disease claims the numbers for those involving accidents has actually reduced. As shown in Table 1, in the past 5 years there has been a 5 per cent fall in the overall number of accident claims. Whereas the number of motor claims has remained remarkably stable, medical negligence claims have fallen by 34 per cent, employers' liability by 21 per cent, and public liability by 7 per cent. It can be seen that motor claims constitute almost 70 per cent of all accident claims in the tort system.

\footnotetext{
${ }^{5}$ Compensation Recovery Unit figures for 2004-2005, and Census Statistics for April 2001 showing that the U.K. population had grown to 58,789,194. See Lewis et al. (2006).

${ }^{6} \mathrm{http}: / /$ www.dti.gov.uk/coalhealth/01.htm.

${ }^{7}$ Stapleton (1986).
} 
The Geneva Papers on Risk and Insurance - Issues and Practice

326

Table 1 The numbers and types of accident claims notified since 2000 (Source: U.K. Compensation Recovery Unit)

\begin{tabular}{rrrrrrr}
\hline & Medical & Employer & Public & Motor & Other & Total \\
\hline $00 / 01$ & 10,980 & 97,675 & 94,000 & 401,740 & 7,815 & 612,120 \\
$01 / 02$ & 9,773 & 97,004 & 100,663 & 400,434 & 6,252 & 614,126 \\
$02 / 03$ & 7,973 & 92,915 & 109,441 & 398,870 & 6,347 & 615,546 \\
$03 / 04$ & 7,109 & 79,286 & 91,177 & 374,740 & 4,874 & 557,186 \\
$04 / 05$ & 7,196 & 77,765 & 86,966 & 402,892 & 4,463 & 579,282 \\
\hline
\end{tabular}

\section{The real defendants}

Although the majority of these claims for injury are brought against defendants who are individual people, almost all of them are insured against their liability. Employers, most organizations and companies, and many public bodies who are sued are similarly insured. The result is that in nine out of ten cases the real defendants are insurance companies, with the remainder comprising large self-insured organizations or public bodies, such as government departments and health authorities.

It is extremely rare indeed for an uninsured individual to be the real defendant. Instead tort defendants are policyholders who cede control over their case to their insurer and thereafter usually play little or no part in the litigation process. For example, Harry Street, former Professor of Law at Manchester University and author of Street on Torts, admitted that he was once a defendant in a case but only discovered that it had been determined on appeal when he read about it in a newspaper. ${ }^{8}$ Insurers in practice determine how the defence is to be conducted. This means, for example, that they commonly make admissions without the consent of the insured, ${ }^{9}$ and they can settle cases in spite of objection from the policyholder. ${ }^{10}$

\section{The paymasters}

Insurers are the paymasters of the tort system, being responsible for 94 per cent of tort compensation for personal injury. ${ }^{11}$ They process the routine payments and they decide which elements of damage they will accept or contest. It is unusual for them to contest liability, one recent study revealing that insurers' files "contained remarkably little discussion of liability," finding it initially denied in only 20 per cent of cases. ${ }^{12}$ As a result, eventually insurers make at least some payment in the great majority of personal injury claims, often because most of them are of very low value. Overall

\footnotetext{
${ }^{8}$ Elliott and Street (1968, p. 209).

${ }^{9}$ Goriely et al. (2002, p. 90).

${ }^{10}$ However, this very wide discretion given to insurers to conduct the litigation behind the insured's back is subject to some limit as recognized in Groom vs. Crocker (1939) 1 KB 194.

${ }^{11}$ The Pearson Commission (1978, vol. 2, para 509). The relative importance to the tort system of road and industrial injuries for which insurers are most likely to be responsible has hardly changed since the Commission reported. See note 42 below.

12 Goriely et al. op cit, p. 103.
} 
about 89 per cent of motor claims and 77 per cent of employers liability claims are successful, ${ }^{13}$ although it has been suggested that of 150,000 cases supported by trade unions, about 95 per cent result in some payment to the claimant. ${ }^{14}$ Tort thus provides a structure for processing mass payments of small amounts of compensation; only very rarely does it stage a gladiatorial contest to determine whether a particular defendant was in the wrong. Contrary to the impression gained from tort textbooks, duty of care, causation of damage, and even breach of duty are generally not in dispute in cases processed by the system.

In the great majority of cases insurers pay not only compensation to claimants, but also the litigation costs of both sides. However, if an action fails the claimant may become liable for costs. To avoid this, after their injury, claimants may be offered by loss insurers a policy which promises to pay their costs in the event of an unsuccessful claim. If the claim proves successful, the premium can be added to the damages awarded in tort. Insurers may also offer such legal expenses insurance in other contexts. For example, it is estimated that around 17 million motor policies and 15 million household policies offer "before the event" legal expenses insurance. The result is that legal expenses insurers now control litigation in 80 per cent of motor accident claims, and their market penetration is expected to continue to increase. ${ }^{15}$ Legal expenses insurance can affect key aspects of the litigation. ${ }^{16}$ In particular, claimants cannot easily choose their own lawyer and may be required to use one from a panel approved by the insurer. ${ }^{17}$ As a result it is estimated that soon almost all road accident cases will be dealt with by no more than a hundred of the 9,000 solicitors' firms nationwide. ${ }^{18}$ The clients of these solicitors may receive a different service compared to those claimants free to choose their own lawyer: conflicts of interest are more likely to arise. ${ }^{19}$ Insurers thus fund the tort system, control much of the representation, and can have an interest in whatever the outcome of a claim.

\section{Insurers' bureaucratic organization}

Classic empirical studies reveal that, in practice, the rules of tort law are much less important than the textbooks might lead one to suppose: it is insurance bureaucracy that dictates the course of litigation procedure and determines whether, when, and for

${ }^{13}$ In 1973, insurers made some payment in 86 per cent of the cases disposed of in the survey for the Pearson Commission (note 11 above) at vol. 2, para 511. However, according to Compensation Recovery Unit figures for 2004-2005 almost all claims involve some payment for only 0.5 per cent are recorded as involving no liability. This figure is noted as unreliable by Marshall and Morris (2003, p. 12). Based on other CRU data for 2002-2003, they suggest that 89 per cent of motor claims and 77 per cent of employers liability claims were successful.

${ }^{14}$ Citizens Advice Bureau (2004, para 4.31).

${ }^{15}$ Smith (2004, p. 17).

${ }^{16}$ Abrams (2002); Fenn et al. (2002).

${ }^{17}$ Blundell (2004, p. 93).

${ }^{18}$ Lawson (2004, p. 17). In 2003, there were 9,211 firms of solicitors in England and Wales according to the Law Society (2004).

19 Abrams op cit, chapters 8 and 9. 
how much, claims are settled. ${ }^{20}$ The important centres of personal injury practice are insurers' buildings, rather than courts of law, or even solicitors' offices. A senior judge has even suggested that solicitors might no longer be involved with small claims where defendants are insured, and that insurers could be left to administer these claims alone. ${ }^{21}$ In effect this is what may happen if a particular reform is brought to fruition: prompted by the Better Regulation Task Force, ${ }^{22}$ the Government is considering whether to raise from $£ 1,000$ to $£ 5,000$ the limit for personal injury claims which may be taken through the small claims procedure without costs being awarded for legal representation. Claimant lawyers are alarmed at the prospect and have campaigned to resist the change. Whether or not this campaign succeeds, it is already the case that insurers' offices are the key places for determining most tort claims. They could be even more important in the future.

The number of such insurance centres has declined recently because of company mergers and greater specialization. The work has been concentrated in particular localities. Consolidation in the general liability market has resulted in it being dominated by only eight major companies, although there are more than 50 other smaller firms issuing policies. ${ }^{23}$ For motor insurance there were over 350 companies authorized to transact motor insurance in 2002, but only 65 companies and 11 Lloyds syndicates actively did so. The 10 largest motor insurers controlled two-thirds of the market. ${ }^{24}$ The three quarters of a million claimants suffering personal injury last year therefore came up against only a few handfuls of real defendants.

In dealing with claims, insurers have developed highly systematized approaches which make extensive use of information technology. Their standard procedures have been refined further for the "fast track" cases involving smaller amounts of money. They closely monitor the performance of not only their in-house claims handlers but also the lawyers they choose to instruct. Striving for efficiency, they have reduced the number of solicitors' firms acting for them. Economic pressures mean that communication between the parties takes place on the telephone rather than via letters or face to face meetings, and the outcome of a claim is likely to be influenced as much by an impersonal computerized assessment as by the discretion of the claims handler involved. ${ }^{25}$ Although these generalizations about how litigation is conducted do not apply to all insurers for every type of case ${ }^{26}$ they have a great effect upon the way in which tort rules are viewed and used in practice.

${ }^{20}$ See Genn (1987); Harris et al. (1984) and, in the U.S.A. context, Ross (1980). The major findings are supported by more recent empirical studies and, in particular, by Goriely et al. op cit. But see the critique of Genn's work in Dingwall et al. (2000, p. 1).

${ }^{21}$ Law Society (2004).

${ }^{22}$ Better Routes to Redress (2004). This Government report concludes that the compensation culture may be a myth, but the perception of it results in real and costly burdens. An account of how tort claims are exaggerated by the media in the U.S.A. is contained in Haltom and McCann (2004). Similarly see Baker (2005).

${ }^{23}$ Parsons (2003, para 5.6).

${ }^{24}$ Association of British Insurers (2004, annex B).

${ }^{25}$ Goriely et al. op cit, pp. 31 and 149.

${ }^{26}$ Dingwall et al. op cit. 


\section{The use of lawyers and courts}

Insurers determine the extent that lawyers become involved in disputes, and the tactics that are used in the proceedings. Increasingly cases are being settled at an early stage, and without resort to the issue of court documents. One survey found all parties in agreement that, after recent reforms of civil procedure, cases were now more likely to be resolved without court involvement. ${ }^{27}$ Major insurers estimated that, because of earlier settlement, the number of cases disposed of only after the issue of formal proceedings had declined by a third. According to the Court Service, the number of new claims issued in the county court has fallen by 32 per cent in the past 5 years. Of course, it has always been the case that the great majority of claims settle informally: 30 years ago 86 per cent of cases were being settled without formal proceedings in the form of a writ being issued. ${ }^{28}$ Now even more cases are being settled at an early stage.

Insurers are avoiding not only courts, but also lawyers. Defence lawyers are being bypassed. In 2004, AXA insurance company announced that it had reduced by half the number of law firms defending its cases. Similarly over a period of 4 years the Zurich insurance company decimated the number of firms representing its policyholders in catastrophic cases: only four firms now defend such cases for this insurer. More generally, the Law Society noted that the number of firms carrying out personal injury work fell from 28 per cent in 1999 to 21 per cent in 2002.

Insurers decide, in particular, whether a case merits the very exceptional treatment of being taken to a court hearing. Before being set down for trial 98 per cent of cases are settled, and many of those that remain in the system are concluded before any hearing takes place. ${ }^{29}$ In one survey only five out of the 762 "ordinary" cases with costs of less than $£ 5,000$ went to trial. ${ }^{30}$ In effect, insurers allow trial judges to determine only 1 per cent of all the claims made. Only a few of these are appealed with the result that the senior judiciary are left to adjudicate upon a small fraction of what are, by then, very untypical cases. Whether an appeal court is to be given an opportunity to examine a point of tort law may depend upon the insurer for, if it serves the insurer's purpose for doubt to remain, the claimant can be paid in full and threatened with a costs award if the action is continued. ${ }^{31}$ In this sense tort principles have been shaped by and for insurers, even though there has been a significant growth in the power and expertise of claimant lawyers in the last 20 years. $^{32}$

${ }^{27}$ Goriely et al. op cit at 159 .

${ }^{28}$ Pearson Commission op cit., vol. 2, Table 12.

29 Ibid.

${ }^{30}$ Pleasence (1998, p. 12). Earlier, Harris et al. op cit had suggested that as many as 3 per cent of cases might go to trial. However, even in cases involving very substantial awards of damages $-£ 150,000$ or more paid by insurers in 1987 and 1988 - only 10 per cent of payments were the result of formal court orders, and most of these related to children or patients for whom court approval of their settlements is required. Cornes (1993, p. 20).

${ }^{31}$ As recognized in Davis vs. Johnson (1979) AC 264 at 278. However, see the failed attempt to prevent the House of Lords considering important causation issues in relation to asbestos liability in Fairchild vs. Glenhaven Funeral Services Ltd. (2002) 1 AC 32 discussed by Oliphant (2003, p. 148).

${ }^{32}$ The contribution of claimant lawyers to the personal injury system merits separate discussion and is not dealt with here. Claimant lawyers are now much more likely to be specialists and work in larger and 


\section{The realities of the settlement system}

Insurers' influence upon settlements is even more pronounced than it is upon decided cases. The lawyer asked by his client to advise on the merits of a claim is concerned with the realities of the litigation system rather than the formal rules of law. Practitioners would agree with the key analysis of Ross ${ }^{33}$ that the textbook rules of tort are often transformed when they come to be used in the system in three ways: firstly, they are simplified; secondly, they are made more liberal; and thirdly, they are made more inequitable.

Simplification occurs because the rules are too uncertain when applied to the individual facts of particular accidents. For reasons of cost and administrative efficiency, insurers have been forced to substitute other criteria for the strict tort rules. Mechanical rules of thumb - such as the car running into the back of another always being found the one at fault - replace any detailed investigation into blame. There is neither the time nor resources to instruct experts to analyse the scene of each road accident and precisely measure its effect upon the individual claimant. Cases are disposed of on the basis of paperwork alone, and this may bear only a limited relationship to what actually occurred.

The result of the cost pressures upon insurers is that the system is very liberal in that many more claims succeed than the strict rules of tort would allow. Often insurers pay something for claims which, on full investigation, would be without foundation. As a result

"...wherever there is insurance there is ... a closer approximation to the objectives of social insurance in fact than the doctrines of tort law would lead one to suppose." 34

However, this liberality is but part of a system which overall is weighted in favour of insurers and results in much inequality. Indeed, the case often used to illustrate the general inequalities in the legal system involves a "one-shotter" accident victim suing a "repeat player" insurer. ${ }^{35}$ Delay, uncertainty, financial need and other pressures cause claimants to accept sums much lower than a judge would award. The eagerness of claimants and their solicitors to get something from the system is reflected in the fact that, in the past, in two out of three cases they accepted the very first formal offer

much better organized firms than in the past. Relying upon Law Society figures, Goriely et al. op cit at footnote 25 note that even before April 2000 (when legal aid was withdrawn for most personal injury claims) solicitors were becoming increasingly specialized, and fewer firms were "dabbling" in such work. The founding of the Association of Personal Injury Lawyers in 1990 and its subsequent activity reflects the increasing abilities and resources of claimant lawyers. Williams (1991, p. 103). The Association now has over 5,250 members, employs 28 people, and has an income of $£ 1.94$ million. APIL, Annual Report and Accounts 2004.

${ }^{33}$ Ross op cit.

${ }^{34}$ Harper and Fleming (1956, s 13.7).

${ }^{35}$ The seminal article is Galanter (1974, p. 9). However, Dingwall et al. op cit emphasize that not all defendants in personal injury cases are "repeat players" and they should not be treated as a homogenous group. Other limits of the article were examined in an anniversary special issue in Law and Society Review (1999, p. 795). 
made to them by the "risk neutral" insurer. ${ }^{36}$ Although a more recent study discloses more bargaining, almost a third of cases are still settled after only one offer, and twothirds settled after two. ${ }^{37}$ Those claimants who can withstand the pressures of litigation do better than those who cannot, with the result that those from a particular class or background are more likely to succeed. ${ }^{38}$ Those who suffer most are the severely injured. Although in the greatest need, they will find their high-value claim scrutinized in detail and processed very differently from the average case which typically involves but a minor upset and little, if any, financial loss. Those seriously injured are much less likely to receive "full" compensation than those suffering minor injury, ${ }^{39}$ although they are left in a much better position than accident victims forced to rely upon state benefits alone. The great majority of claimants quickly recover from their minor injury and, for a variety of reasons, are likely to emerge over-compensated for their economic loss. ${ }^{40}$

The overall result of the settlement system is that rough and ready justice is dispensed, much influenced by the insurance company personnel and procedures, and driven by the needs of the insurance industry and the cost of the legal process. The system produces arbitrary results and bears only a limited relationship to the portrayal of justice contained in the traditional tort textbook.

\section{The effects of compulsory insurance}

The importance of insurers to the tort system is reflected in the fact that the claims which are brought closely match the areas where liability insurance is to be found. Thus road and work accidents predominate partly because those are the two major areas where tort insurance is compulsory. ${ }^{41}$ They constitute 86 per cent of all the claims brought for personal injury, with motor comprising 53 per cent of the total and employer liability 33 per cent. ${ }^{42}$ They dominate the practice of tort even though they constitute a minority of all accidents, and are an even smaller percentage of the causes of all forms of disablement and incapacity for work. One survey found the more common accidents were those in the home, or suffered in the course of leisure activities

${ }^{36}$ D. Harris et al. op cit Table 3.3 .

${ }^{37}$ Goriely et al. op cit at 154 . Leech (2005) reports that her firm accepted only a quarter of the first offers made in 540 settled cases.

38 Ross op cit.

${ }^{39}$ As illustrated in relation to particular types of claim in Lewis et al. (2002a, p. 406; 2002b; 2002c, p. 1042; 2003, p. 568).

${ }^{40}$ Dewees et al. (1996, p. 19); Bell and O’Connell (1997, pp. 63-66).

41 The lack of coherent policy behind compulsory insurance was traced by Lewis (2004, p. 1474). See also Parsons (1999, p. 109).

42 Compensation Recovery Unit figures for 2004-2005. Similarly, Datamonitor, U.K. Personal Injury Litigation 2004, Figure 5. The nature of litigation in this respect has hardly changed for the Pearson Commission figure of 88 per cent for road and employment claims combined is exactly the same as that now being reported almost thirty years later. Pearson Commission, op cit vol. 2, Table 11. Atiyah (1997, p. 99) suspected that the relative proportion of claims had not changed. 
or in playing sport, and yet very few of these resulted in any damages award. ${ }^{43}$ Although work and transport injuries dominate the tort system, at best they are the cause of only about half of all accidents, ${ }^{44}$ and some surveys suggest that they are much less important than this. For example, it has been estimated that there were 7.8 million accidents in the home in 1999 but in only 0.5 per cent of these was there the potential for a successful tort claim. ${ }^{45}$

All this means that the place where you are injured is crucial. Accidents in areas not covered by liability insurance are extremely unlikely to be compensated. According to one study, whereas one in four road accident victims and one in ten work accident victims get something from tort, only 1 in 67 injured elsewhere do so. ${ }^{46}$ Overall, only one accident victim in 16 who is incapacitated for 3 days or more is compensated by the tort system. However, if we concern ourselves only with serious injuries, tort becomes much more important; where an accident causes incapacity for work for 6 months or more, almost a third of victims receive tort damages. However, this increased significance of tort can then be severely undermined; the importance of the tort system is reduced tenfold if account is taken of those suffering disablement not from accidents alone, but from all causes, including congenital illness and disease. ${ }^{47}$ Tort then has only a very marginal role to play, and is insignificant compared to the provision made by social security and the welfare state.

The scope of the tort system is affected not only by the areas where liability insurance has been made compulsory, but also by the existence of alternative sources of compensation. What opportunities are there for resorting to either welfare payments from public insurance, or policy monies from first-party private insurance? These may reduce the incentive to pursue a common law claim. The interrelationship of compensation systems cannot be discussed in detail here, ${ }^{48}$ but one example will suffice to demonstrate the potential effects of other insurance systems upon tort. ${ }^{49}$ The example is a historical one and, in practice, resulted in the abandonment of tort law for the great majority of work injuries. It derives from the "election" rule whereby workers injured in the course of their employment had to choose either to sue in tort or to claim private insurance benefits on a no-fault basis from their employer. They could not do both by obtaining these insurance benefits and pursuing an action in tort. For a variety of reasons employees overwhelmingly opted, or were pressed into receiving, the no-fault benefits, ${ }^{50}$ leaving the tort system with a very limited role to play in the industrial field. 51 There was judicial criticism of the "deplorable" and "extremely shabby" tactics used by insurers to prevent tort claims being pursued. ${ }^{52}$ Eventually the

\footnotetext{
${ }^{43}$ Harris op cit Table 2.1.

${ }^{44}$ Pearson op cit vol. 2, Table 57. In Australia, they are less than a fifth according to Luntz and Hambly (2002, p. 4).

45 Datamonitor (2003) at 79.

${ }^{46}$ The Pearson Commission op cit vol. 1, Table 5.

47 Atiyah op cit., p. 100.

48 See Lewis (2003).

${ }^{49}$ For a second example of the influence of insurance upon litigation see Lewis (1985, p. 275).

${ }^{50}$ Dinsdale (1954, p. 161)

${ }^{51}$ Bartrip (1987, chapter 10).

${ }^{52}$ Deane vs. H. F. Edwards \& Co. (1941) 34 BWCC 183.
} 
"employer privilege" was abolished in $1948,{ }^{53}$ and since that time tort claims for work accidents have flourished, now constituting a third of all the actions brought in the U.K. ${ }^{54}$ The privilege continues in North America, a few European countries, and increasingly in Australia.

\section{Insurers and the award of damages}

This influence of insurance upon the general pattern of tort liability is matched by its effect upon the level of compensation awarded. In the U.S.A. it is very clear that individual damages awards have been affected by the policy limits set by insurers. There is evidence that lawyers do not pursue claims beyond these limits in order to obtain "blood money" from defendants personally. ${ }^{55}$ However, in the U.K., the policy limits for a claim are almost never relevant. The unlimited basis of insurer liability is graphically illustrated by a case arising from the Selby rail disaster, where a negligent motorist caused a railway accident resulting in his insurer being liable to various claimants for a total of $£ 22$ million. ${ }^{56}$ Owing to of the absence of policy limits in the U.K. it is less easy to see the precise effect of insurance cover in the individual case. However, here it is argued that the principles upon which damages are assessed implicitly recognize that it is a company with a deep pocket that will pay and not an individual, and this is fundamental to the continued existence of the personal injury system.

Most awards in tort are for very limited sums - little more than $£ 2,500 .{ }^{57}$ However, in 2002 insurers estimated that 1 per cent of cases resulted in a payment of $£ 100,000$ or more, and that these were responsible for 32 per cent of the total damages paid out by the system. ${ }^{58}$ There are very few individuals who could afford to pay the amounts required in these serious injury cases. The justice of the case never merits an investigation into the limited means of the average person found liable because that person will not have to pay. It is clear that "the size of damages awards ... is explicable only on the basis that judges are influenced by the widespread presence of insurance." 59 This is a major point. The possibility of awarding millions of pounds in damages all to be paid in one lump sum distinguishes tort from welfare and other compensation systems. Liability insurance enables tort to espouse its distinctive rhetoric: it purports to make an assessment of loss that is not only tailored to the individual claimant, but sufficient to restore the position before injury took place.

\footnotetext{
${ }^{53}$ Law Reform (Personal Injuries) Act 1948.

${ }^{54}$ Compensation Recovery Unit figures for 2004-2005 and Datamonitor (2004, Figure 5).

55 Baker (2001, p. 275).

${ }^{56}$ Great North Eastern Railway vs. Hart [2003] EWHC 2450; (2004) Journal of Personal Injury Law, C 1-4.

${ }^{57}$ This is the median figure in the survey of 81,000 cases receiving legal aid and closed in 1996-1997 in Pleasence op cit., p. 40, Figure 3.17. In 70 per cent of successful cases the damages were less than $£ 5,000$, although the overall average was $£ 11,000$. Fenn and Rickman (2003) report average damages of only $£ 3,000$ for employers liability accident claims, although this study of almost 100,000 cases related only to claims for less than $£ 15,000$. See http://www.dca.gov.uk/majrep/claims/elclaims.htm.

58 Lord Chancellor's Department (2002, Table 1).

${ }^{59}$ Cane (1999, p. 204).
} 
When set against the results achieved in practice these claims are greatly overstated, ${ }^{60}$ and yet they form much of the reason for tort's existence. Without a mechanism to distribute the cost of imposing liability, it would rarely be worth assessing damages in the way we do at present in serious injury claims. Without insurance it is doubtful whether the tort system would survive at all. ${ }^{61}$ Insurance, in this sense, provides the lifeblood of tort.

In recent years major changes have been made to the assessment of damages, and many of these are predicated upon payment being made either by insurers or other large self-insured bodies. The assessment of damages has become ever more precise. Actuarial and forensic accountancy evidence has become commonplace. Such matters as the discount rate for early receipt of damages, ${ }^{62}$ the interest rate on delayed payment, ${ }^{63}$ and the inflation factor enabling past awards to be compared with those of the present day have all been more closely linked to the wider financial world. In a few serious injury cases lump sum payment has been replaced in part by a structured settlement, a reform prompted, manufactured and, until recently, controlled by insurers and insurance intermediaries. ${ }^{64}$ It is impossible to conceive of such developments - involving continuing lifetime obligations to make increasing payments - if it were not for the fact that individuals almost never pay tort damages themselves. The argument here is that it is not easy to divorce these changing rules on assessment and payment of damages from the fact that it is insurers who run the tort system.

\section{Insurers, legislation and pressure group politics}

One of the main reasons for U.K. insurers forming their own trade association in 1917 was in order to respond to potential changes in the law. ${ }^{65}$ The Association of British Insurers (ABI) has since grown to such an extent that, with the exception of the National Farmers' Union, it is now more than twice the size of any other trade association. ${ }^{66}$ With an annual budget of over $£ 20$ million, it has been very effective in putting forward the industry's point of view. Its lobbying of government ministries is such that one insurance commentator has even suggested that, internationally, institutions such as the ABI "see themselves as governing governments." 67

The ABI has also ensured that its case is heard in Parliament. Until 1997 one in 10 Members of Parliament declared a financial link with the insurance industry, ${ }^{68}$ although this figure has now been halved. The author's more recent examination of the

\footnotetext{
${ }^{60}$ See note 39 above.

${ }^{61}$ Fleming (1988, p. 21).

${ }^{62}$ Law Commission (1994).

${ }^{63}$ Law Commission (2004).

${ }^{64}$ Lewis (1994, p. 18). Lewis (1993) and Goldrein and de Haas (1997). Under the Courts Act 2003 s 100 courts now have power to order that damages take this periodic form even if insurers object. See Lewis (forthcoming).

${ }^{65}$ Its history is traced in Catchpole and Elverston (1967).

${ }^{66}$ Boleat (1997, p. 21).

${ }^{67}$ Ericson et al. (2003, p. 151). See also Ericson and Doyle (2004).

${ }^{68}$ Clarke (1997, p. 281).
} 
Register of Members' Interests revealed that only eight members of the House of Lords declared an insurance interest, one being membership of Lloyds. In contrast, 15 Members of Parliament declared connections with insurance companies, and a further 19 recorded that they were current or former members of Lloyds.

The regulatory framework of insurance reflects the success of the ABI in arguing for forms of self-regulation in lieu of statutory controls, and for exemption from general legislation that might otherwise apply. The clearest example of this is the last minute exemption of insurance policies from domestic legislation dealing with control of unfair contract terms, a result described by the former Director General of Fair Trading as "amazing." 69 Owing to of such influence, insurance remains the least regulated of contracts.

The ABI is organized so as to respond to all government proposals to change the wide areas of law with which it is concerned, these extending far beyond the law of tort. In 1998, the U.K. government announced that no proposal for regulation which has an impact upon businesses would be considered by ministers without a "regulatory impact assessment" being carried out. Rather than being just another bureaucratic requirement, the new procedures offer business and industry a major opportunity to influence the policy and legislative process. ${ }^{70}$ Parliamentary Bills are now accompanied by impact statements assessing the financial costs and benefits of the measures being proposed. In drawing up such statements civil servants are directed to consult widely. Twenty or so bodies are specifically named, one of them being the ABI. ${ }^{71}$ As a result, it is automatic for the ABI to be asked to estimate the effect of proposed reforms on insurance premiums. Insurability is therefore now a relevant consideration whenever statutory changes affecting tort are being considered. Although these impact statements have given insurers a formal opportunity to make representations to government, it is doubtful whether this has increased their influence very much. This is because their most effective representations continue to be exercised in private, behind closed doors. $^{72}$

One illustration of the effectiveness of such private lobbying is the overturning of a Law Commission recommendation that a particular financial formula be used to set the discount rate in assessing damages for personal injury. In the Damages Act 1996, the Commission's recommendation was replaced by a power given to the Lord Chancellor to change the rate as he saw fit. However, this discretionary power was not exercised for some time, and when a rate was eventually set it was less favourable to claimants than if the Commission's formula had been used. The Opposition spokesman in Parliament noted that the change in the Act was "mightily convenient to the insurance industry" and commented that it was the result of "whispering in appropriate ears." 73

\footnotetext{
${ }^{69}$ Borrie (1984, p. 110).

${ }^{70}$ Miller (2000, p. 251). More generally see Rush (1990) and Grant (1989).

${ }^{71}$ Cabinet Office (2003).

${ }^{72}$ See Boleat, op cit chapters 7 and 8, and especially 61-64.

${ }^{73}$ Discussed in more detail in Lewis (1997, p. 230).
} 


\section{Conclusion}

Most of the facts we have cited about insurers and personal injury litigation have been proven time and again. They derive from a series of empirical studies, each broadly confirming the general picture. ${ }^{74}$ However, tort textbooks pay them little, if any, attention. ${ }^{75}$ In spite of law students being left in ignorance, it cannot be denied that insurers are fundamental to the operation of the tort system. "Insurance "technology" underlies the whole practice of tort law." 76 It is not merely an ancillary device to protect the insured, but is the "primary medium for the payment of compensation, and tort law [is] a subsidiary part of the process." 77 Without insurance the tort system "would long ago have collapsed under the weight of the demands put on it and been replaced by an alternative, and perhaps more efficient system of accident compensation." 78 Of what that system might compose is beyond the scope of this article, ${ }^{79}$ but we are left with an appreciation of the importance of insurers to tort law, and a denial of the claim that insurance has had only a limited effect upon the system.

\section{References}

Abrams, P. (2002) In Safe Hands? Funding Litigation by Legal Expenses Insurance, London: University of Westminster.

APIL (2004) Annual Report and Accounts 2004.

Association of British Insurers (2004) Response to the Greenaway Review of Compulsory Motor Insurance and Uninsured Driving, London: ABI.

Atiyah, P.S. (1997) The Damages Lottery, Oxford: Hart Publishing.

Baker, T (2001) 'Blood money, new money and the moral economy of tort law in action', Law \& Society Review 35: 275.

Baker, T. (2005) The Medical Malpractice Myth, Chicago: University of Chicago Press.

Bartrip, PWJ (1987) Workmen's Compensation in Twentieth Century Britain, Aldershot: Avebury.

Bell, P.A. and O'Connell, J. (1997) Accidental Justice: The Dilemmas of Tort Law, New Haven, CT: Yale University Press.

Better Regulation Task Force (2004) Better Routes to Redress (May), pp. 1-13.

Blundell, H. (2004) 'Free to Choose? BTE Legal Expenses Insurance and Freedom of Choice', Journal of Personal Injury Law (June): 93.

Boleat, M. (1997) Trade Association Strategy and Management, London: Association of British Insurers.

Borrie, G. (1984) The Development of Consumer Law and Policy-Bold Spirits and Timorous Souls, London: Stevens.

\footnotetext{
${ }^{74}$ Extensively referenced in Dewees et al. op cit. However, see Saks (1992, p. 1147).

75 The major exception being P. Cane, op cit especially chapter 9. There is little useful discussion of the effect of insurance on tort liability in the many student and practitioner texts with the exception of Jones (2002, s.1.3) and Deakin et al. (2003). There are few insurance textbooks compared to tort, but they similarly avoid the discussion. A notable exception is the excellent section in Clarke (2005, chapter 8).

${ }^{76}$ Steele (2004, p. 36).

${ }^{77}$ Cane op cit. p. 191.

${ }^{78}$ Fleming (1998, p. 13).

${ }^{79}$ Sugarman (1998). One alternative was given in Sugarman (1989), and another in Ison (1994). These solutions can be contrasted with one which has been much criticized because it relies upon first party insurance as the foundation for radical reform. See Atiyah op cit.
} 
Cabinet Office (2003) Better Policy Making: A Guide to Regulatory Impact Assessment, available at http:// www.cabinet-office.gov.uk/regulation/scrutiny/ria-guidance.pdf.

Cane, P. (1999) Atiyah's Accidents, Compensation and the Law, 6th edn., London: Butterworths.

Catchpole, W.L. and Elverston, E. (1967) BIA Fifty, Stockport: P.H. Press.

Citizens Advice Bureau (2004) No Win, No Fee, No Chance (December).

Clarke, M.A. (1997) Policies and Perceptions of Insurance, Oxford: Clarendon Press.

Clarke, M.A. (2005) Policies and Perceptions of Insurance, Oxford: Oxford University Press.

Cornes, P. (1993) Coping with Catastrophic Injury, Edinburgh: Rehabilitation Studies Unit.

Datamonitor (2003) U.K. Personal Injury Litigation 2003, London.

Datamonitor (2004) U.K. Personal Injury Litigation 2004, London.

Davies, M. (1989) 'The end of the affair: duty of care and liability insurance', Legal Studies 9: 67.

Deakin, S., Johnson, A. and Markesinis, B. (2003) Tort Law, 5th edn., Oxford: Oxford University Press.

Dewees, D., Duff, D. and Trebilcock, M. (1996) Exploring the Domain of Accident Law: Taking the Facts Seriously, Oxford: Oxford University Press.

Dingwall, R., Durkin, T., Pleasence, P., Felstiner, W. and Bowles, R. (2000) 'Firm handling: the litigation strategies of defence lawyers in personal injury cases', Legal Studies 20: 1.

Dinsdale, W.A. (1954) History of Accident Insurance in Great Britain, London: Stone and Cox.

Elliott, D.W. and Street, H. (1968) Road Accidents, London: Penguin.

Ericson, R.V. and Doyle, A. (2004) Uncertain Business: Risk, Insurance and the Limits of Knowledge, Toronto: University of Toronto Press.

Ericson, R.V., Doyle, A. and Barry, D. (2003) Insurance as Governance, Toronto: University of Toronto Press.

Fenn, P. and Rickman, N. (2003) 'Costs of Low Value Liability Claims 1997-2002', available at http:// www.dca.gov.uk/majrep/claims/elclaims.htm.

Fenn, P., Gray, A. and Rickman, N. (2002) The Impact of Sources of Finance on Personal Injury Litigation, Lord Chancellor's Department No 7/02.

Fleming, J. (1948) 'Accident liability reconsidered: the impact of liability insurance', Yale Law Journal 57: 549-551.

Fleming, J.G. (1988) The American Tort Process, Oxford: Clarendon Press.

Fleming, J.G. (1998) The Law of Torts, 9th edn., Sydney: LBC Information Services.

Galanter, M. (1974) 'Why the 'Haves' Come Out Ahead', Law and Society Review 9: 95.

Genn, H. (1987) Hard Bargaining, Oxford: Clarendon Press.

Goldrein, I. and de Haas, M. (eds) (1997) Structured Settlements: A Practical Guide, 2nd edn., London: Butterworths.

Goriely, T., Moorhead, R. and Abrams, P. (2002) More Civil Justice? The Impact of the Woolf Reforms on Pre-Action Behaviour, London: The Law Society and the Civil Justice Council.

Grant, W. (1989) Pressure Groups, Politics and Democracy in Britain, Hemel Hempstead: Philip Allan.

Haltom, W. and McCann, M. (2004) Distorting the Law: Politics, Media, and the Litigation Crisis, Chicago: University of Chicago Press.

Harper, F.V. and Fleming, J. (1956) The Law of Torts, Boston: Little Brown \& Co.

Harris, D., Maclean, M., Genn, H., Lloyd-Bostock, S., Fenn, P., Corfield, P. and Brittan, Y. (1984) Compensation for Illness and Injury, Oxford: Clarendon Press.

Ison, T. (1994) Compensation Systems for Injury and Disease: The Policy Choices, Toronto: Butterworths. Jones, M. (2002) Textbook on Torts, 8th edn., Oxford: Oxford University Press.

Law and Society Review (1999) Law and Society Review 33.

Law Commission (1994) Structured Settlements and Interim and Provisional Damages, Report No. 224.

Law Commission (2004) Pre-Judgement Interest on Debts and Damages, Report No. 287.

Law Society (2004) 'Insurers should run small claims', Law Society Gazette (29th April).

Law Society (2005) Key Facts 2004: The Solicitors' Profession (January).

Lawson, S. (2004) 'BTE insurance - a threat to the profession or new opportunities?' Personal Injury Focus 14(3): 17.

Leech, C. (2005) 'Better in than out', Law Society Gazette (January 6): 10.

Lewis, R. (1985) 'Insurers' agreements not to enforce their strict legal rights', Modern Law Review 48 : $275-292$. 
Lewis, R. (1993) Structured Settlements: The Law and Practice, London: Sweet \& Maxwell.

Lewis, R. (1994) 'Structured settlements: an emergent study', Civil Justice Quarterly 13: $18-28$.

Lewis, R. (1997) 'Lobbying and the Damages Act 1996: 'Whispering in Appropriate Ears”, Modern Law Review 60: 230-237.

Lewis, R. (2003) 'Tort and social security, in U. Magnus (ed) The Impact of Social Security Law on Tort Law, Vienna: Springer, pp. 56-85.

Lewis, R. (2005a) 'Insurance and the Tort System', Legal Studies 25(1): 85-116.

Lewis, R. (2005b) 'The relationship between tort law and insurance in England and Wales, in G. Wagner (ed) Tort Law and Liability Insurance, Vienna: Springer, pp. 47-85.

Lewis, R. (2006) 'The politics and economics of tort law: Judicially imposed periodical treatments of damages', Modern Law Review 69(2) (forthcoming).

Lewis, R. (2004) 'The duty to insure', New Law Journal 154(7147): 1474.

Lewis, R., McNabb, R., Robinson, H. and Wass, V. (2002a) 'Court awards of damages for loss of future earnings: an empirical study and an alternative method of calculation', Journal of Law \& Society 29: $406-435$.

Lewis, R., McNabb, R., Robinson, H. and Wass, V. (2002b) 'Court awards of damages for loss of future earnings: an empirical study and an alternative method of calculation', Journal of Personal Injury Law, $151-165$.

Lewis, R., McNabb, R., Robinson, H. and Wass, V. (2002c) 'A new way to assess damages for loss of future earnings', New Law Journal 152: 1042.

Lewis, R., McNabb, R., Robinson, H. and Wass, V. (2003) 'Loss of earnings following personal injury: do the courts adequately compensate injured parties?' Economic Journal 113: 568-584.

Lewis, R., Morris, A. and Oliphant, K. (2006) 'Tort personal injury claims statistics: Is there a Compensation Culture in the U.K.?' Torts Law Journal 16(2) (forthcoming).

Lord Chancellor's Department (2002) Regulatory Impact Assessment on the Courts Bill (November).

Luntz, H. and Hambly, D. (2002) Torts: Cases and Commentary, 5th edn. Sydney: Butterworths.

Marshall, D. and Morris, A. (2003) 'Resolving a burning fees issue', Litigation Funding 26: 12.

Miller, C. (2000) Political Lobbying, London: Politico's.

Morgan, J. (2004) 'Tort, insurance and incoherence', Modern Law Review 67: 384-392.

Oliphant, K. (2003) 'England and Wales, in H. Koziol and B.C. Steininger (eds) European Tort Law 2002, Vienna: Springer.

Parsons, C. (1999) 'Employers liability insurance - how secure is the system?' Industrial Law Journal 28(2): $109-132$.

Parsons, C. (2003) An Analysis of Current Problems in the U.K. Liability Insurance Market, Office of Fair Trading Report, London: OFT659a.

Pearson Commission (1978) The Pearson Commission Report of the Royal Commission on Civil Liability and Compensation for Personal Injury, Cmnd 7054.

Pleasence, P. (1998) Personal Injury Litigation in Practice, London: Legal Aid Board Research Unit.

Prosser, W.L. (1971) Law of Torts, 4th edn. St Paul, MN: West Publishing Co.

Ross, H.L. (1980) Settled Out of Court, New York: Aldine Publishing.

Rush, M. (1990) Parliament and Pressure Politics, Oxford: Clarendon Press.

Saks, A. (1992) 'Do we really know anything about the behaviour of the tort litigation system - and Why Not?' University of Pennsylvania Law Review 140: 1147.

Smith, P. (2004) 'Panel solicitors: the legal expense insurer's perspective', Personal Injury Focus 14(3): 17.

Stapleton, J. (1986) Disease and the Compensation Debate, Oxford: Oxford University Press.

Stapleton, J. (1995) 'Tort, insurance and ideology', Modern Law Review 58: 820.

Steele, J. (2004) Risks and Legal Theory, Oxford: Hart Publishing.

Sugarman, S. (1989) Doing Away with Personal Injury Law, New York: Quorum.

Sugarman, S. (2004) 'Personal injury and social policy - institutional and ideological alternatives', in N. Mullany and A. M. Linden (eds) Torts Tomorrow, Sydney: LBC Information Services.

Williams, M. (1991) 'A. P. I. L.', Civil Justice Quarterly 19: 103. 


\begin{abstract}
About the Author
Professor Richard Lewis teaches tort and insurance law at the University of Cardiff Law School. He has published extensively in the areas of accident compensation, and public and private insurance. He is the author of the award-winning book Structured Settlements: The Law And Practice, having previously written Compensation For Industrial Injury. His most recent book is Deducting Benefits From Damages For Personal Injury, published by the Oxford University Press. He has contributed over a 100 articles to academic and professional journals, and is a well-known speaker at conferences, particularly those dealing with personal injury.
\end{abstract}

